\title{
遅れ破壊の初期き裂の発生条件についで
}

\author{
宮 本 博** 江 藤 元 大** $^{* *}$
}

\section{A Study on Initial Crack-Nucleating Condition in Delayed Fracture}

by

\author{
Hiroshi MiYAmoto \\ (Faculty of Engineering, Tokyo University, Tokyo) \\ and Gendai ETO
}

(Faculty of Engineering, Chiba Institute of Technology, Narashino)

In the preceding report, the effects of hydrogen upon various characteristics of steel were found by performing the static bending test and delayed fracture test on the specimens in which hydrogen was introduced by acid dipping.

In this report, the initial crack-nucleating condition in delayed fracture has been obtained based on the plastic solution of A.P. Green et al. for a sharply V notched specimen and the experimental results of the preceding report. And also the maximum stress to nucleate a crack when hydrogen is introduced has been obtained by using the calculation and the diagrams.

Furthermore, the static bending test and delayed fracture test were performed on the high strength hexagon bolts in order to ascertain whether this result can be applied in practice. And it has been found that the crack-nucleating stress obtained is applicable.

(Received July 26, 1972)

\section{1 緒言}

前報に打いて，熱処理により強度を変えた低炭素ボ ロン鋼のシャルピー型曲げ試験片について, 10\%硫酸 水溶液に30分間浸せきした後での静的曲げ試験，10\% 硫酸水溶液中での遅れ破壊試験, 沶よび, 平滑試験片 を10\%硫酸水溶液に30分間浸せきした後での引張試験 を行ない，水素の鋼に対する種々の特性を見いだすこ とができた。その括もなものは, 遅れ破壊限度以下の 負荷応力では，切欠き底付近に，き裂の発生が見られ なかったこと、鋼に外部より水素が侵大する場合，そ の侵入深さが非常に浅い表面層のみであったこと、拉 よび, 鋼に水素を導入しても, 降伏応力には差がみら れなかったことなどである。

今回は，これらの実験結果を基にして，遅れ破壊の 初期き裂の発生条件などを求めようとしたものである.

\section{2 遅れ破壊き裂の伝ぱ}

$10 \%$ 硫酸水溶液中での遅れ破壊のき裂伝ぱは, 前報 の結果より, Fig. 1 の過程に従うものと考觉られる.

\footnotetext{
* 本報を「遅れ破壞に関する研究(第 2 報)」(A Study on Delayed Fracture, II) とする.

原稿受理 昭和 47 年 7 月 26 日

** 正 会 員 東京大学工学部 東京都文京区本郷

*** 千葉工業大学 習志野市谷津町
}

まず，一定荷重下の試験片を10\%硫酸水溶液に浸せき すると表面から水素が侵入する。 しかし, その侵入深 さは表面層のみである，つぎに，切欠き部前方に特い て応力により，微細き裂が発生する，微細き裂は成長 して切欠き底と結合し, き裂内部にまで硫酸水溶液が 侵入する，そこで，さらに水素はき裂底前方に侵入す る。そして，そこで，新たに微細き裂が発生し，また， き裂底と結合する。このような過程を経て, 遅れ破壊 き裂は伝ぱする。

ここで, 遅れ破壊限度以下の負荷応力の場合, 実験 結果により，切欠き底付近にき裂の発生がみられなか ったことから，洋れ破壊さ裂の伝ぱする条件を満たす ことができない，このため，遅れ破壊は発生しなかっ たものと考光られる。したがって，切欠き底でき裂が 発生することが, 遅れ破壊を発生させることになる。 これらのことから，切欠き底でのき裂発生条件を求め ることが必要になってくるわけである。

\section{3 切欠き底での弾塑性応力分布}

A. R. Troiano などの研究では, 遅れ破壊の初期き 裂は切欠き底前方で発生し, 切欠き底からの距離は, 切欠き底の丸味半径の大小によって決をり, 丸味半径 が大きければ，距離が大きくなることを実験的に確認 


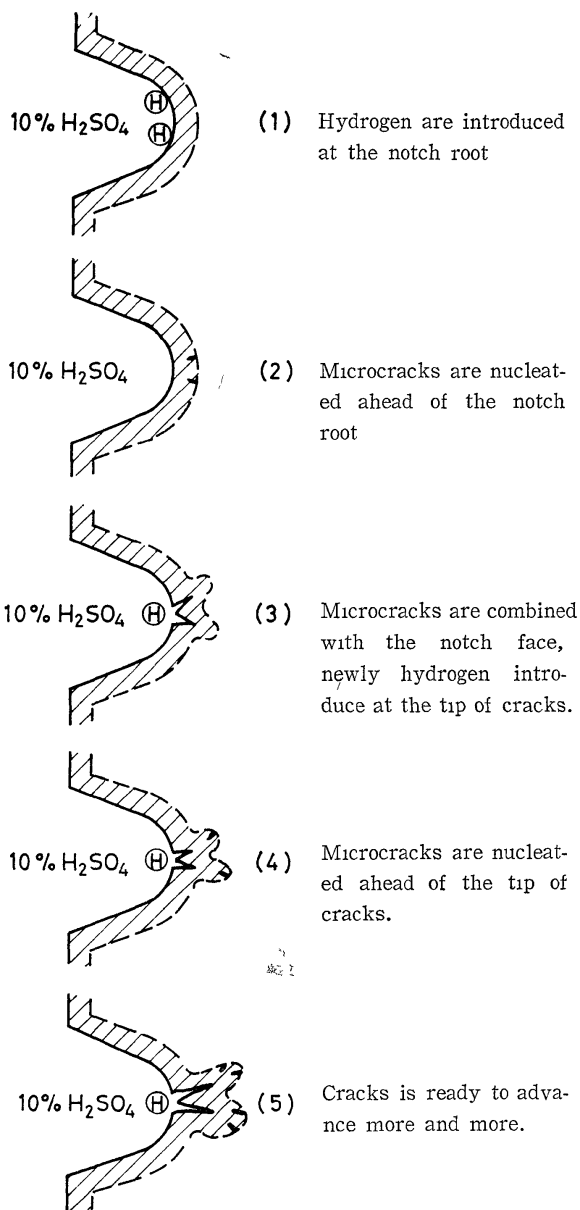

Hydrogen-embrittled region

Fig. 1. The process of crack advance in delayed fracture.

している．この原因としては，切欠き底前方の三軸応 力状態の高い静水圧力部分で, き裂が発生するためで あるとしている。

一方, 鋼に水素を導入しても, 降伏応力は変化しな いことから, 少なくとも, 切欠き底では応力集中によ り，降伏を起こした後でき裂が発生することは充分考 えられる、また, 多くの実験結果から, 遅れ破壞を起 こさせるには, 特に高強度の鋼を除いて切欠きがある ことが必要条件となっている。したがって, 公称応力 が低くても切欠き底では，降伏を起こしていることは 明らかである。これらのことから，弾塑性的な考え方 を切欠き底に適用した。

Fig. 2 は, 切欠き底での弾塑性応力分布を示したも のである.この場合, 切欠き底では単軸引張りの降伏 応力となり，塑性域の大きさRが大きくなるにつれて 縦方向応力 $\sigma_{y}$ は増加する. しかし, 塑性域が $R_{\beta}$ に 達すると, $\sigma_{y}$ は $\sigma_{y}{ }^{\max }$ に達し, それ以上には大きく

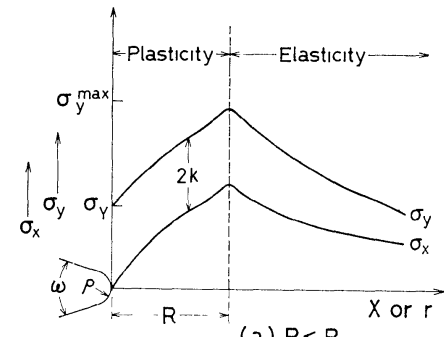

(a) $R<R_{\beta}$

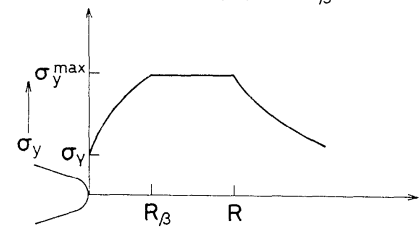

(b) $R>R_{\beta}$

Fig. 2. Variation of $\sigma_{y}$ and $\sigma_{x}$ with distance $r$ ahead of a notch at a given value of plastic zone size $R$. (a) $R<R_{\beta}$. (b) $R>R_{\beta} . R_{\beta}$ is the value of $R$ at which $\sigma_{y}$ max is first raised to its maximum value.

なり得ない。

ここで, A.P. Green などの, すべり線場理論によ るV型切欠き付シャルピー試験片の解を使用すると,

塑性域の大きさ $R$ 大゙, $O<R \leqq R_{\beta}$ の場合,

$$
\begin{gathered}
\sigma_{y}=2 k\left\{1+l_{n}\left(1+\frac{R}{\rho}\right)\right\} \\
k: \text { せ九断降伏応力 } \\
\rho: \text { 切欠さ底丸味半径 }
\end{gathered}
$$

また， $\sigma_{y}^{\max }$ は，

$$
\sigma_{y}^{\max }=2 k\left(1+\frac{\pi}{2}-\frac{\omega}{2}\right)
$$

$\omega$ : 切欠きの開き角度

最初に, $\sigma_{y}{ }^{\max }$ に達する時の塑性域の大きさ $R_{B}$ は,

$$
R_{\beta}=\rho\left(\mathrm{e}^{(\pi-\omega) / 2}-1\right)
$$

となる。(1)式より, 切欠き底半径が一定であれば，塑 性域が大きくなるにつれて $\sigma_{y}$ は増加し，(2)式より， 最高值 $\sigma_{y} \max$ は切欠きの角度 $\omega$ に依存する。李た， $\sigma_{y}{ }^{\max }$ に達する時の塑性域の大きさ $R_{\beta}$ は，(3)式より， 切欠き角度 $\omega$ が決むれば, 切欠き底半径 $\rho$ にっって決 まることを示している。

\section{4 遅れ破壊初期き裂の発生条件}

以上のことから，遅れ破壊初期き裂の発生条件を求 めてみると, Fig. 3 のよらになる。すなわち, 切欠き 底での縦方向応力 $\sigma_{y}$ の分布は, 図の $\mathrm{ABC}$ のように なる。これに対して, 水素の侵入深さをHとすると, 切欠き底表面で最も強度が低下し，（しかし，その值 は単軸引張りの降伏点以上である.） $H$ の距離で水素 の影響は全然なくなるものと考㝋られる。そして，そ の間での強度の変化は不明であるが，Hの距離が実際 には小さいため，ほぼ直線的に変化するものと仮定す 


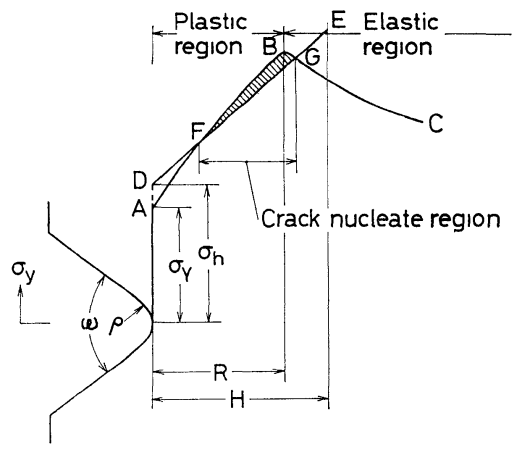

Fig. 3. The intial crack nucleate condition on the notch specimen that was introduced hydrogen. $\mathrm{ABC}$ : Distribution of the normal stress $\sigma_{y}$ ahead of the notch root. DE: Condition of the decrease in strength by introducing hydrogen. $\sigma_{Y}$ : Uniaxial tensile yield stress. $\sigma_{h}$ : Decrease in strength by hydrogen at the surface.

る(図の DFGE)。すると，図の斜線部分では，(FG 部分）応力 $\sigma_{y}$ の方が材料の水素により低下した強度 より高くなり，この範囲では降伏を起こさずに， $\sigma_{y}$ によりき裂が発生するるのと考光られる。これが，遅 れ破壊初期き裂の発生条件である。これらのことから， 遅机破壊を起こさない条件として, Fig. 4 の3 例が考 兄られる.Fig. 4 (a)は，切欠き角度が大きな場合で， $\sigma_{y}{ }^{\max }$ は低くなるため，き裂は発生しない。また， Fig. 4 (b)は，切欠き底丸味半径が大きいために， $R_{B}$ が大きくなり結果的にはき裂が発生しがたい，Fig. 4 (c)は，公称応力が低いため，塑性域の大きさ $R$ ガ小さ く, $\sigma_{y}$ の值も小さいので, き裂は発生しない。これ は遅れ破壊限度以下の負荷応力の場合に相当する。

\section{5 塑性域の大きさ $R$ と, 公称応力との関係}

静的曲げ試験汇括汀る，応力ーたわ及線図と塑性域 の大きさRとの関係を示したのが Fig. 5 である. 図の 応力ーたわみ線図は，実験で得られた線図を模式化し たものである、実線で示したのは，脱水素処理を行な った試験片の結果であり, 破線で示したのは, 水素を 導入した試験片の結果である。まず，脱水素処理を行 なった試験片では, 図の(1)の点で切欠き底で降伏を開

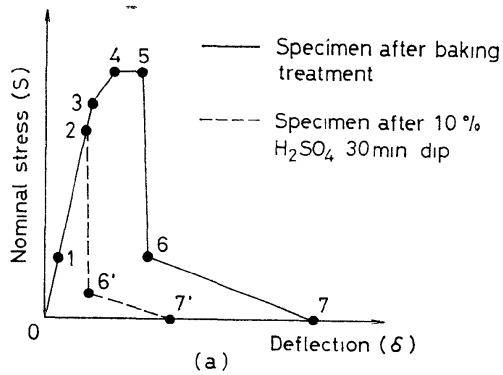

(a)
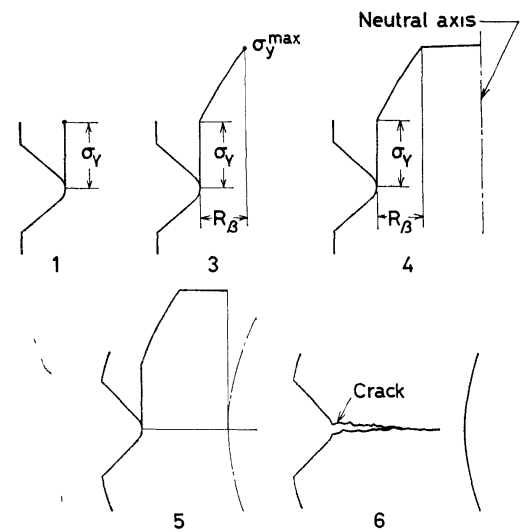

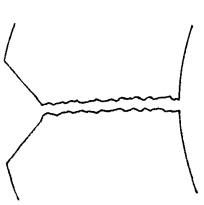

7

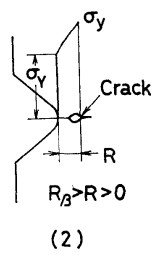

(b)
Fig. 5. (a) The schematic diagram of result on static bending test, and (b) the condition of stress distribution at each point and the condition of crack.

始する、この点は, 実際には，応力集中により切欠き 底が単軸引張降伏応力に等しくなるときの公称応力特 よびたわみを示す点である。つぎに，(3)の位置で， $\sigma_{y}{ }^{\max }$ 飞達し(比例限応力と考学られる), (3)と(4)の 間は， $\sigma_{y}{ }^{\max }$ の応力で塑性域は内部へ進行する。そし て，(4)の位置で全面降伏を起こし，試験片は大きくた
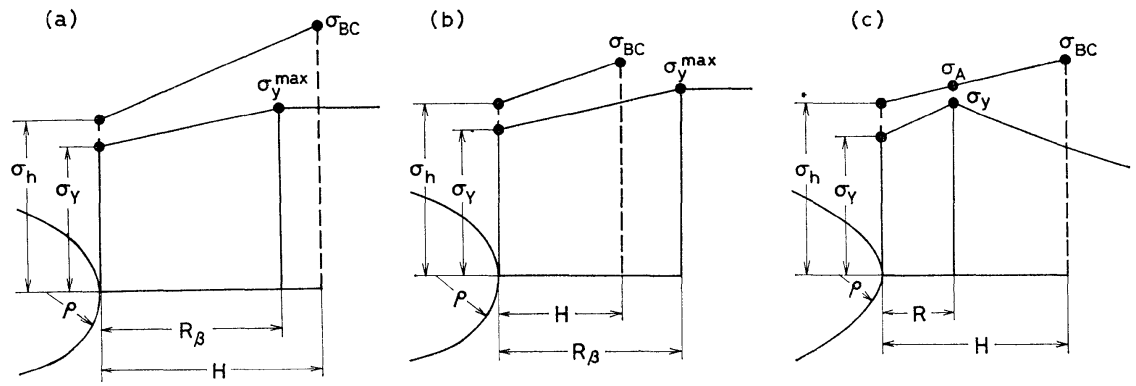

Fig. 4. The condition that initial crack in delayed fracture is not occured. 
わみ始める。穾験では，(4)-(5)の範团で，き裂が発生 し，(5)の位置付近で急速に伝ぱする．このため，荷重 も急激に低下寸る。その後，(7)の位置で試験片は分離 破断する.

一方，水素を導入した試験片では，(2)の位置付近で， き裂が発生し，(7) でやはり分離破断する。

ここで，(2)の位置では， $\sigma_{y}^{\max }$ より低い応力 $\sigma_{y_{1}}$ で， き裂が発生したことになる。もちろん，塑性域の大さ さRは $R_{\beta}$ より小さいはずである.これらのことから， 前回行なった実験結果より，水素を導入したときの静 的曲げ試験に括けるき裂発生応力 $\sigma_{y 1}$, および，遅れ 破壊限度の応力 $\sigma_{y 2}$ を求めることがでさる。

\section{6 き裂発生応力の求め方}

静的曲げ試験抏よび引張試験結果は，Table Iのと 和りである。まず，Fig. 5 の(a)の(1)の公称応力を $S_{b}$, また，塑性域の大きさが $R_{\beta}$ となったときの公称応力 を $S_{a}$ (比例限応力) とすると，

Table I. Mechanical properties of specimen.

\begin{tabular}{|c|c|c|c|c|}
\hline & & \multicolumn{3}{|c|}{$\left(\mathrm{kg} / \mathrm{mm}^{2}\right)$} \\
\hline & & No. 1 & No. 2 & No. 3 \\
\hline \multirow{2}{*}{ Tensile test } & Tensile strength & 117.6 & 106.5 & 95.3 \\
\hline & Yield stress & 111.9 & 103.3 & 91.9 \\
\hline \multirow{3}{*}{$\begin{array}{l}\text { Static } \\
\text { bending } \\
\text { test }\end{array}$} & Bending strength & 257.8 & 233.6 & 219.7 \\
\hline & Proportional limit & 255 & 228 & 217 \\
\hline & $\begin{array}{r}\text { Crack nucleate stress } \\
\text { (nominal) }\end{array}$ & & 194.8 & 204.3 \\
\hline $\begin{array}{l}\text { Delayed } \\
\text { fracture } \\
\text { test } \\
\end{array}$ & $\begin{array}{l}\text { Delayed fracture test } \\
\text { (nominal) }\end{array}$ & 60 & 76 & 121 \\
\hline
\end{tabular}

$$
\begin{array}{lll}
S_{b} & \text { で } & R=0 \\
S_{a} & \text { で } & R=R_{\beta}
\end{array}
$$

また， $S_{b}$ から $S_{a}$ までは，荷重と塑性域の大きさ $R$ は一次的な関係にあるとされているので, $S_{b} \leqq S \leqq S_{a}$ の任意の公称応力 $S$ に対しては，塑性域の大きさ $R$ は 簡単に比例関係から次式により求められる。

$$
R=\frac{R_{B}}{S_{a}-S_{b}}\left(S-S_{b}\right)
$$

(4)式に(3)式を代入すると，

$$
R=\frac{\rho\left(e^{(\pi-\omega) / 2}-1\right)}{S_{a}-S_{b}}\left(S-S_{b}\right)
$$

(5)式を(1)式代入すると，

$$
\sigma_{y}=2 k\left[1+\ln \left\{1+\frac{\left(e^{(\pi-\omega) / 2}-1\right)}{S_{a}-S_{b}}\left(S-S_{b}\right)\right\}\right]
$$

ここで, $S_{b}=\sigma_{Y} / \alpha$ を(6)式に代入し，トレスカの降 伏条件 $\sigma_{Y}=2 \cdot k$ を用いると，

$$
\begin{aligned}
\sigma_{y}=\sigma_{Y}\left[1+\ln \left\{1+\frac{\left(e^{(\pi-\omega) / 2}-1\right)}{\alpha S_{a}-\sigma_{Y}}\left(\alpha S-\sigma_{Y}\right)\right\}\right] \\
\text { ただし, } \alpha: \text { 形状係数 } \\
\sigma_{Y}: \text { 単軸引張降伏応力 }
\end{aligned}
$$

(7)式に扣いて，実験に使用した試験片の形状係数 $\alpha$ は，ノイバーによれば， $\alpha=4.1$ であるから，実験結 果より求めた公称応力を代入すれば，水素を導入した ときのき裂発生応力 $\sigma_{y 1}$ ，物よび，遅れ破壊限度の応 力 $\sigma_{y 2}$ を求めることができる.

つぎに，これらの関係を図より求めようとしたのが Fig. 6 である.Fig. 6 の(a)は，塑性域の大きさ $R$, 縦方向応力 $\sigma_{y}$ の関係を示すもので, この関係は, (1) 式による.Fig. 6 の(b)は，塑性域の大きさ $R$ と, 試験 片とのたわみの関係を示し，また，Fig. 6 の(c)は，試 験片の公称曲げ応力と，たわみとの関係を示したもの である.この関係は，比例限応力以下の場合であるか ら，材料の強度が異なっても試験片形状が同一であれ ば，同一直線上になる。また， $R_{\beta}$ の值は，試験片切 欠き角度 $45^{\circ}$ で切欠き底丸味が $0.25 \mathrm{~mm}$ であるから， (3)式より， $R_{\beta}=0.56 \mathrm{~mm}$ となる. したがって，R= $0.56 \mathrm{~mm}$ で $\sigma_{y}{ }^{\max }$ に達することになる. 塑性域は， $S_{b}$ で $R=O$ 比例限応力 $S_{a}$ で $R=R_{\beta}$ となり，その間は， 応力と塑性域の大ささが一次的な関係を有するものと して直線で結んだ。
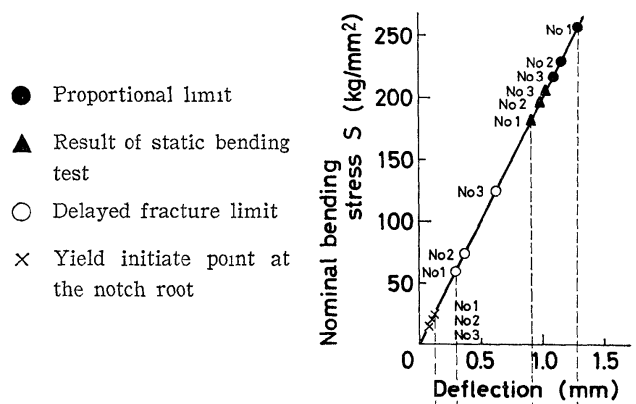

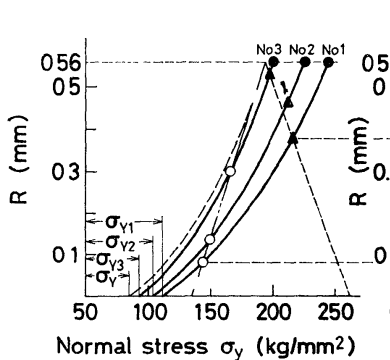

(a)

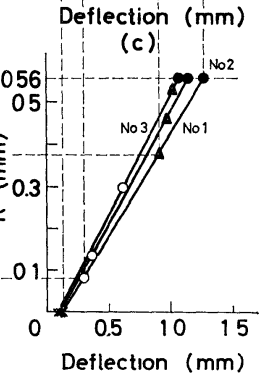

(b)
Fig. 6. The diagrams for obtaining the crack nucleate in static bending test and normal stress $\left(\sigma_{y}\right)$ at delayed fracture limit upon the steel that was introduced hydrogen.

いま，実験結果より求めた，水素を導入したときの 静的曲げ試験のき裂発生公称応力, 特よび, 遅れ破壊 限度をFig. 6 (c) に記入し, Fig. 6(b)から, 各応力に和 ける塑性域の大きさを求め，Fig. $6(\mathrm{a})$ から，縦方向応 力 $\sigma_{y 1}$ 特よび $\sigma_{y 2}$ を求める. この操作を各強度ごと に行なえば, 各強度の $\sigma_{y 1}$ 叔よび $\sigma_{y 2}$ を求めること 
Table II. Test results.

\begin{tabular}{c|c|c|c} 
& \multicolumn{3}{c}{$\left(\mathrm{kg} / \mathrm{mm}^{3}\right)$} \\
\hline Normal stress & No.1 & No.2 & No.3 \\
\hline $\begin{array}{c}\text { Crack nucleate stress } \sigma_{c 1} \\
\left(10 \% \mathrm{H}_{2} \mathrm{SO}_{4} 30 \mathrm{~min} \text { acid dip) }\right.\end{array}$ & 215 & 211 & 197 \\
Delayed fracture limit $\underset{c 2}{\sigma_{c 2}}$ (In $\left.\mathrm{H}_{2} \mathrm{SO}_{4}\right)$ & 144 & 149 & 165 \\
\hline
\end{tabular}

ができる。

以上の方法で求めた，水素を導入したときのき裂発 生応力 $\sigma_{y 1}$, 拈よび, 遅れ破壞限度応力 $\sigma_{y 2}$ を Table II 示京.

つぎに，Fig. 6(a)k和いて，同材質の強度を変光た 試験片に水素を導入した場合のき裂発生応力 $\sigma_{y 1}$ を結 んだ線と, 遅れ破壞限度応力 $\sigma_{y 2}$ を結えだ線とが, $R$ $=R_{\beta}$ の位置で，ほぼ一点で交わるので，この交点よ り逆に, この材料の遅れ破壊を起こさない上限の降伏 応力 $\sigma_{Y O}$ を求めることができる。 また，この点は， 静的曲げ試験のみでも求めることができることを示し ている.実際に使用した低炭素ボロン鋼の場合， $\sigma_{Y C}$ は $85 \mathrm{~kg} / \mathrm{mm}^{2}$ である。

また, 静的曲げ試験は, 短時間で容易に行ならこと ができるが，遅れ破壞試験は長時間を要する。しかし， この図を利用すれば, 強度の異なった数種類の試験片 そついて, 静的曲将試験を行ない， $\sigma_{y 1}$ を求めて特き, つぎに同材質の任意の強度に打汸る遅れ破壊試験を一 種類行ない $\sigma_{y 2}$ を求め机ば, 眓上り任意の強度につい ての遅れ破壊限度を類推することができる。

さらに，これらの図から，材料が同じでも，強度が 上昇すると, き裂の発生点位置は, 切欠き底汇近づく ことを意味し,わずかの水素の侵入量でも初期き裂が 発生しやすいことを示している.

7 水素を導入した場合のき裂発生応力 $\sigma_{y 1}$ および 遅れ破壊限度の応力 $\sigma_{y 2}$ の応用

以上の方法で求められた $\sigma_{y 1}, \sigma_{y 2}$ が実際に利用で きるかどらかを確かめるために，次の実験を行なった． すなわち, 試験片と同材質, 同強度のボルトを10\%硫 酸水溶液に30分浸せき後, JIS で決められているくさ び引張試験 (Fig. 7), 特ょび, ボルトをくさびを介し て締め付け，10\%硫酸水溶液に浸せきする遅孔破壊試 験を行なった。(Fig. 8) これらの試験はいずれもボル ト全体に曲げを生じさせる苛酷な試験である。実際の 高力ボルトの遅れ破壊の発生位置は, 頭部首下丸味部 と不完全ねじ部である. Fig. 9 はこの部分の塑性応力 分布, および, $\mathrm{V}$ 型切欠さ付シャルピー試験片の応力 分布と, この場合の 3 種類の強度の $\sigma_{y 1}$ 拈よび $\sigma_{y 2}$ を同時に示したものである。

まず，この図から，No.1，No.3 の強度のいずれも，

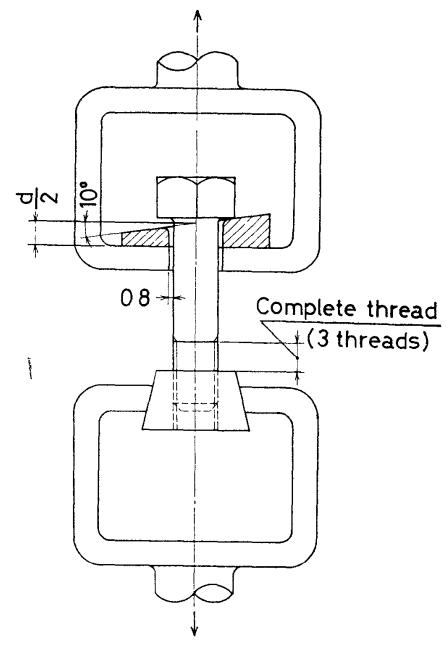

Fig. 7. Equipment of test for strength under weadge loading of full size bolt. (JISB 1051)

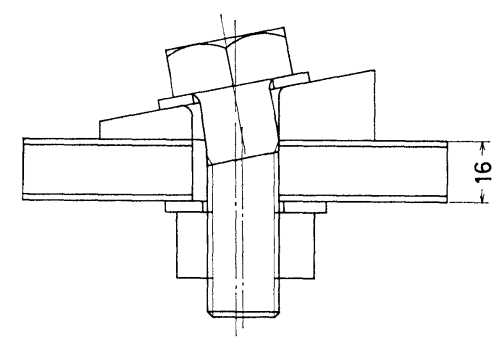

Fig. 8. Equipment of delayed fracture test of full s1ze bolt.

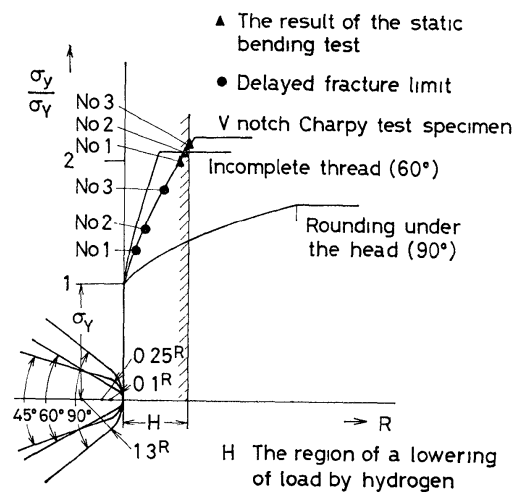

F1g. 9. Plastic stress distribution at vicinity of notch root.

不完全対じ部に括いて，遅机破壊を起こすことは明ら かである.しかし，ここで, No. 1 の強度を除いては, 首下丸味部では， $\sigma_{y}{ }^{\max }$ は遅和破壊限度応力より低く なっているので，き裂を発生する抢各れはない，乙か し, No. 1 の強度では, 水素の侵入深さを $H$ (実験結 果から $0.5 \mathrm{~mm}$ 以内）とすると，き裂を発生する可能 性のあることを示している。実際の僬机破壞試験結果 では, No.1, No. 3 の強度のボルトの両方共, 不完全 


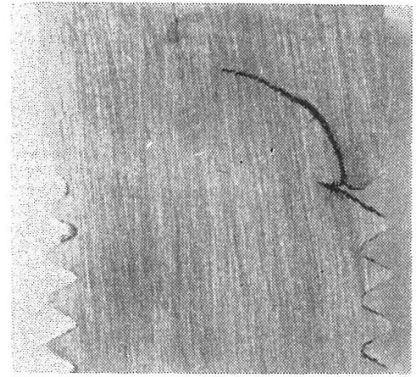

Fig. 10. The aspect of crack propagation of the bolt, after $10 \% \mathrm{H}_{2} \mathrm{SO}_{4}$ dip in test for strength under weadge loading of full size bolt, (incomplete thread).

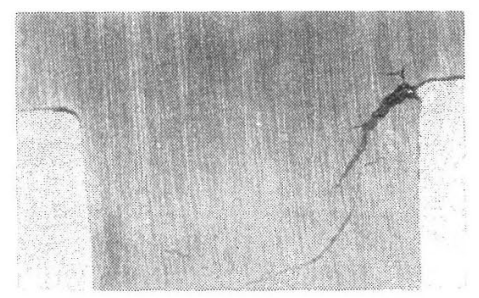

Fig. 11. The aspect of crack propagation of the bolt, in delayed fracture test in $10 \% \mathrm{H}_{2} \mathrm{SO}_{4}$ (rounding under the head).

衫じ部より遅れ破壊を起こした。(Fig. 10) そして， No. 1 の場合，首下丸昧部に多試験後ボルトを繸方向 に切断して調べた結果，き裂の入っていることが涩め られた。(Fig. 11)

一般に，〈さび引張試験の場合，水素を導入しない ものの引張強度は，首下に平座金を拽入した引張試験 の引張強度との間に大きな差がないのが普通である。 これは,くさびによって曲げを受けても, 全面降伏を 起こすまでにき裂が発生することがないためである。 しかるに，No.1 に相当するボルトでは，水素を導入 することにより $34 \%$ bの最高応力の低下がみられた。 しかし，No.3のボルトでは，㴗とえど強度の低下は みられなかった。このことは，No. 1 に相当するボル 卜は，全面降伏を起こす以前にさ裂が発生したために， 最高応力が低下したが，No. 3 については，Fig. 9 か b, 裂発生応力口方が, 縦方向応力 $\sigma_{y}$ より高いた
め，全面降伏を起こしてもき裂は発生せず，このため 差が出なかったものと考党られる。

これらの実験結果は, 求めたき裂発生応力 $\sigma_{y 1}$ 和上 び遅れ破壞限度応力 $\sigma_{y 2}$ が，実際に，応用できること 定示している。また， $\sigma_{y 1}, \sigma_{y 2}$ は，材質，強度和よび 水素の侵入量によって決沓る固有の量で市り, 切欠き 底での仙力分布は, 試験片切欠きの形状によって決ま るものであるから， $\sigma_{y 2}$ 以下に $\sigma_{y}{ }^{\max }$ がなるような切 欠弆形状を選べば，遅机破壞発生の可能性はなくなる 当のと考光られる。

$$
8 \text { 結言 }
$$

水素が鋼中に入って発生する遅れ破壞は，切欠き底 に初期き裂が発生することが必要条件であると考觉ら れる。このき裂は，切欠き底前方で生ずる高い縦方向 応力によって生じ, その大きさは, 単軸引張降伏応力 $\sigma_{Y}$ 以上で, 最大縦力向心力 $\sigma_{y}{ }^{\max }$ より低くくなるの で，実駩結果より，き裂発生応力また遅れ破壞限度の 応力を計算または図により求めることができる。求る られたこれらの応力は，実験により，実際に応用でき ることがわかった。切欠さの形状によって，最大縦方 向応力を低くすることができれば，き裂は発生せず， したがって，切欠き形状の变更によって遅れ破壊を防 止することは可能である。

(昭和 47 年 5 月 30 日 日本材料学会第 21 期総会学術講演会にて講濱)

\section{参考 文 献}

1) 宮本 博, 江藤元大, 材料, 21，223 (1972).

2) Troiano, A. R., H. H. Johnson and J. G. Morlet, Trans. AIME, 212, 528 (1958).

3) Tetelman, A.S., "Fracture of Structural Materials," 邦訳 宮本 博 (1970) 培風館

1) Green, A. P., and B. B. Hundy, J. Mech. Phys. Solids, Vol. 4 (1956).

5) Hill, R., The Mathematical Theory of Plasticity, 邦訳（1954）培風館

6）JIS B 1051, ボルト，小ねじの機械的性質.

7）JSSC, 高力ボルトの遅机破壊, 6, No. 52. (1970). 